\title{
AUKŠTŲJŲ MOKYKLŲ SISTEMA LIETUVOJE 1940-1990 METAIS: RAIDOS BRUOŽAI
}

\author{
Aušrinè Zulumskytė \\ Klaipédos universitetas
}

\begin{abstract}
Anotacija
Straipsnyje pristatoma Lietuvos aukštujų mokyklų raidos apžvalga sovietmečio laikotarpiu. Pateikiami chronologiniai Lietuvos aukštujų mokyklų kūrimosi bei transformacijų duomenys 1940-1990 metais, pradedant sovietine okupacija ir baigiant Atgimimo metu i̇vykiais. Išryškinama sovietmečio Lietuvos aukštujų mokyklų struktūra ir veiklos specifika, pristatomas specialistų rengimo turinys, mokslo ir studijų sąlygos bei pobūdis. Apie aukštojo mokslo raidą Lietuvoje sovietmečiu iki šiol neparengta chronologiškai vientisų, išsamių mokslo darbų. Daugiausiai informacijos apie ši laikotarpi teikia tik pavieniai archyviniai dokumentai, sovietmečio periodine spauda, proginès knygos, skirtingų aukštujų mokyklų leidiniai apie savo institucijos istorija, mokslininkų memuarai, kai kurie aukštojo mokslo raidos bruožai atskleidžiami pavieniuose mokslo darbuose. Pateikiama apibendrinta ivvairių autorių darbų ir šaltinių analizė apie Lietuvos aukštojo mokslo sistemos plètrą sovietmečiu.

PAGRINDINIAI ŽODŽIAI: aukštasis mokslas, aukštosios mokyklos, Lietuva.
\end{abstract}

\begin{abstract}
This article presents the review of the development of Lithuanian higher schools during the Soviet period. Chronological data of establishment and transformations of Lithuanian high-schools in 1940 1990 are presented, beginning with the Soviet occupation and ending with the Revival events. The article highlights the structure and specifics of Soviet Lithuanian high-schools, the content of specialists training, provisions of science and studies. Chronologically integral, comprehensive scientific works about higher education development in Soviet Lithuania have not been prepared yet. Most of the information about this period is provided by individual archival documents, Soviet periodical press, commemorative books, different high school publications on the history of their institution, as well as individual researchers memoirs, some features of the development of higher education are revealed in individual scientific works. This article provides an summarized material of various authors and sources and integral analysis of Lithuanian higher education during the Soviet period. KEYWORDS: higher education, higher schools, Lithuania.
\end{abstract}

\section{Ivadas}

Aukštojo mokslo institucijų ištakos Lietuvoje siekia XVI amžiaus antrają pusę, taigi pirmasis Lietuvos universitetas skaičiuoja jau penktaji gyvavimo šimtmetị. Kitų Lietuvos aukštujų mokyklų kūrimasis tesiekia XX amžiaus pirmosios pusès 3-4 dešimtmečius, o kai kurių pradžia - tik XX a. antroji pusè. Ne visi šie istoriniai laikotarpiai švietimo ir ugdymo mokslo raidos kontekste išanalizuoti pakankamai. Lietuvos aukštojo mokslo sistemos, esminių raidos bruožų pažinimas pirmiausia sietinas su visuminiu krašto kultūrinio paveldo pažinimu, leidžiančiu suprasti ir atsakyti i dabarties visuomenès gyvenimo iššūkius. 
Apie Lietuvos aukštojo mokslo ištakas (Vilniaus universiteto istoriją) sukaupta pakankamai istoriografinès ir faktinès medžiagos, parengta pažintinių leidinių, o apie kitų mūsų šalies aukštujų mokyklų ỉsikūrimą ir raidą informacijos aptinkama kur kas mažiau. Ypač problemiška tai, kad apie aukštojo mokslo plètrą Lietuvoje sovietmečiu iki šiol neparengta išsamesnių, chronologiškai susistemintų darbų. Sovietmečio laikotarpis lietuviškojo ugdymo mokslo ir švietimo istorijos kontekste apskritai laikytinas „baltaja dème“, kadangi po sovietinès santvarkos griūties Lietuvoje aukštosios mokyklos reformavosi, jungèsi, kai kurių senuju vietoje steigėsi naujos, tad sovietmečio aukštujų mokyklų archyvai beveik neišsaugoti: labai daug sovietmečio knygų, nuotraukų, kitos dokumentinès medžiagos XX a. pabaigoje išimta iš tuometinių institutų ir aukštesniujų mokyklų kabinetų, muziejų ir net nacionalinès bibliotekos fondų. Ši medžiaga sunaikinta impulsyviai - nespèjus ižvelgti jos istorinio vertingumo, atsirasiančio po kurio laiko bandant atkurti sovietinio meto kultūros, mokslo, visuomeninio gyvenimo realijas. Yra išlikusių kai kurių sovietinio laikotarpio knygų, kurios susijusios su šia tematika (pvz., Novodvorskis, 1964; Kauno medicinos institutas, 1967; Bendžius, 1973 ir pan.), laikraščiu ir žurnalų straipsnių (pvz., Sprindys, 1951; Volenskytė, 1952; Mironas, 1958; Leonavičius, 1961 ir pan.), statistinių dokumentų rinkinių (pvz., Lietuvos TSR aukštosios mokyklos, 1965; 1966 ir pan.), tačiau šių ir panašių leidinių informaciją būtina kritiškai peržiūrèti, ivvertinant aptariamojo laikotarpio ideologijos ir propagandos nulemtą turini.

Daugiausiai faktinès informacijos apie ši laikotarpi teikia tik pavieniai archyviniai dokumentai, išlikusi sovietmečio periodinė spauda, proginès knygos, skirtingų aukštujų mokyklų pažintiniai leidiniai apie savo institucijos istoriją, taip pat pavieniai mokslininkų memuarai, kai kurie aukštojo mokslo raidos bruožai atskleidžiami pavieniuose moksliniuose straipsniuose. Vienas žinomiausių autorių, tyrinejjusių šią problematiką, - Algimantas Liekis (2000; 2001; 2003 ir kt.), savo darbuose analizavęs kai kurių aukštujų mokyklų raidos ypatumus, Lietuvos mokslų akademijos raida, kitus sovietmečio akademinio gyvenimo klausimus. Tačiau chronologiniai aukštojo mokslo sistemos kūrimosi XX a. antrojoje pusėje aspektai moksliniuose darbuose atskleisti tik epizodiškai.

Taigi aktuali problema, kad Lietuvos aukštojo mokslo raidos XX amžiuje mokslinė analizè kol kas gana fragmentiška, neišbaigta, tad straipsnyje pateikiamas istoriografinis tyrimas leistų papildyti švietimo ir ugdymo mokslo istoriją chronologiškai susisteminta medžiaga ir naujomis įžvalgomis, kurios sudarytų prielaidas ši laikotarpi vèliau tyrinèti ir kitais probleminiais aspektais.

Tyrimo objektas - Lietuvos aukštojo mokslo sistema 1940-1990 m.

Šio straipsnio tikslas: atskleisti kai kuriuos Lietuvos aukštojo mokslo sistemos raidos bruožus 1940-1990 metais. 
Uždaviniai:

- pristatyti aukštojo mokslo situaciją Lietuvoje XX a. 4-ojo dešimtmečio pabaigoje;

- išryškinti esminius Lietuvos aukštojo mokslo pokyčius pirmosios sovietinès okupacijos laikotarpiu ir pirmaisiais II pasaulinio karo metais (naciu okupacijos laikotarpiu);

- atskleisti antrosios sovietinės okupacijos nulemtas permainas krašto aukštojo mokslo sistemoje;

- aptarti pagrindinius aukštojo mokslo raidos ir plètros aspektus Lietuvoje XX a. 6-9 dešimtmečiais bei Atgimimo metais.

Tyrimo metodai: mokslinės literatūros analizè, istoriografinès ir dokumentinès medžiagos analizè, lyginamoji analizè.

\section{Aukštojo mokslo padètis Lietuvoje pasitinkant penktajii dešimtmetị}

Seniausia Lietuvos aukštoji mokykla - Vilniaus universitetas - ikurta dar 1579 metais. Iki pat 1940 metų Vilniaus universitetas išgyveno daugybę politinių peripetijų. Kadangi Lietuvos sostiné Vilnius ir dalis Rytų Lietuvos 1919-1939 metais buvo okupuota Lenkijos, vieninteli klasikinį universitetą bandyta gaivinti laikinojoje sostineje Kaune. Dar 1920 metais būrelis įvairių profesijų šviesuolių Kaune issteigè Aukštuosius kursus. 1922 metais jie pavadinti Lietuvos universitetu Kaune (Liekis, 2001, p. 61). 1930 metais minint Lietuvos didžiojo kunigaikščio Vytauto 500 metų mirties sukaktį, šiai institucijai Lietuvos Vyriausybė suteikè Vytauto Didžiojo universiteto vardą (Vytauto Didžiojo universitetas: atmintis, žmonès, idèjos, 2008). 1940 metų pavasari čia veikè penki fakultetai: Teologijos-filosofijos, Matematikos ir gamtos, Medicinos, Statybos ir Technologijos.

Pagal 1939 m. spalio 10 d. sutarti su SSRS, Lietuvai atgavus Vilnių, tuometine Lietuvos Vyriausybė ir visuomenè susirūpino ir senojo Vilniaus universiteto atkūrimu. Vilniaus universitetas vèl pradejo veikti 1940 m. sausio pradžioje (Universitas Vilnensis 1579-2004, 2004, p. 41). Jo pagrindą sudare keli fakultetai, perkelti iš Kauno su studentais ir profesūra. Vilniaus universiteto rektoriumi tada išrinktas kultūros istorikas, 1918 metų Nepriklausomybès akto signataras Mykolas Biržiška.

Iki 1940 metų Lietuvoje jau veikẻ nemažai studijų institucijų, turinčių arba siekiančių aukštojo mokslo statuso.

Nuo 1924 metų Dotnuvoje veikè Žemès ūkio akademija (Liekis, 2000, p. 11). 1940 metais joje veikè Agronomijos, Miškininkystès ir Namų ūkio fakultetai, buvo 13 katedru, mokèsi apie 300 studentų. 
1933 metais Kaune veikusios muzikos mokyklos pagrindu ikurta Kauno konservatorija, kuri laikytina aukštojo muzikinio mokslo Lietuvoje pradžia (Narbutienè, 1993, p. 3). 1940 metais čia veikẻ vargonu, fortepijono, orkestrinių instrumentų, dainavimo ir kompozicijos klasès. Jose mokèsi apie 300 studentų.

1934 metais Klaipèdoje įsteigtas Prekybos institutas (Lazauskienè, 2009, p. 6). Klaipėdos kraštą okupavus vokiečiams, 1939 metais Prekybos institutas perkeltas ị Šiaulius. 1940 metais institute veike trys skyriai: banku, prekybos ir konsultacinis, mokèsi apie 170 studentų. Šis institutas veike tik penkerius metus (iki 1944 m.), tačiau išleido apie 150 absolventų (Ten pat, p. 54).

1934 metais Kaune issteigti Aukštieji kūno kultūros kursai (Stonkus, 2007, p. 45). 1938 metais, patenkinus tuometinius specialistų poreikius, kursai uždaryti. Tačiau tuometinė Lietuvos švietimo ministerija Aukštuosius kūno kultūros kursus pripažino kaip aukštają mokyklą.

Pirmoji aukštoji pedagoginė mokykla Lietuvoje buvo Respublikos pedagoginis institutas, 1935 metais ikurtas Klaipèdoje (Tijūnèlienè, 1996, p. 8). Vokiečiams užėmus Klaipèdos kraštą Klaipėdos pedagoginis institutas 1939 m. pavasari perkeltas į Panevėží, 1939 m. rudeni - i Vilnių (Visuotinè lietuvių enciklopedija, t. 10, p. 219).

1936 metais Kaune atidaryta Veterinarijos akademija (Bružauskas, Čaplikas, Kirstukas ir kt., 2007). 1940 metais ji nepadalinta į fakultetus, bet turëjo 9 katedras, čia mokèsi apie 100 studentų.

1939 metais isteigta Kauno meno mokykla, kuri 1940 metais pavadinta Taikomosios dekoratyvinès dailès mokykla, dar po metu - Taikomosios ir dekoratyvinès dailès institutu (Liekis, 2001, p. 92). Vilniaus universitete veikęs Dailès fakultetas perorganizuotas į Vilniaus dailès mokyklą, o 1941 metais, jau sovietų valdžios sprendimu, pavadintas Vilniaus dailès akademija.

1939 metais ịkūrus Lituanistikos institutą žengti pirmieji žingsniai ir Mokslų akademijos kūrimo link (Genzelis, 2001, p. 212), Lietuvos mokslo akademija ịkurta 1941 metu pavasari (Liekis, 2001, p. 313).

Taip Lietuvoje sukurtas tuometinius šalies poreikius atitinkantis aukštujų mokyklų tinklas, kuriuose sutelktas ir mokslo tiriamasis darbas. Apskritai ikisovietinèje Lietuvoje nebuvo tokios mokslo, technikos, kultūros ar ekonomikos srities, $\mathfrak{i}$ kurią savo indèlio nebūtų inešę tuometinių aukštujų mokyklų mokslininkai, dèstytojai, studentai. Iš viso 1940 metais Lietuvoje buvo apie 600 mokslo darbuotoju (iskaitant ir aukštujų mokyklų dėstytojus), apie 90 iš jų turèjo mokslo laipsnius. Daugiausia jų būta medicinos, technikos, menotyros, filologijos, žemès ūkio srityse (Ten pat, p. 93). 


\section{Pirmoji sovietinė okupacija ir II pasaulinio karo laikotarpis valdant nacistinei Vokietijai}

1940 metų vasarą Sovietų Sajungai okupavus Lietuvą, aukštosios mokyklos pradètos pertvarkyti pagal sovietinę sistemą ir ideologiją. $1940 \mathrm{~m}$. vasarą Vytauto Didžiojo universitetas neteko savo garbingo pavadinimo ir imtas vadinti tiesiog Kauno universitetu (Liekis, 2003). Sovietinè valdžia šiame universitete iš karto uždarè Teologijos-filosofijos fakultetą (Liekis, 2001, p. 92).

Aukštosiose mokyklose sustabdyta visų studentiškų korporacijų ir sajungu („Ateities“, „Grandies“ ir kitı) veikla. Tačiau Vilniaus universiteto, VDU studentai neišsiskirstè, aktyviai veikẻ pogrindyje ir buvo vieni iš 1941 metu sukilimo prieš okupacinę valdžią organizatorių bei dalyvių (Vytauto Didžiojo universitetas: atmintis, žmonès, idejjos, 2008).

Studijos pradètos brutaliai sovietizuoti. Politiniais motyvais iš aukštujų mokyklų šalinti sovietinei santvarkai nepalankūs profesoriai, studentai. Didelẻ dalis intelektualų, šviesuomenès ištremti į Sibiro lagerius, iš kurių daugelis nebegrižo. Nemaža dalis pasitraukè ị Vakarus (Liekis (red.), 2000, p. 12-13).

Prasidejus pirmajai sovietinei okupacijai, mokymo programos aukštosiose mokyklose sparčiai ir kardinaliai pakeistos (Germanas, 1987, p. 101). Visose studiju institucijose pradètas dèstyti karinis parengimas, marksizmas-leninizmas, sukarinta medicinine praktika.

Daugelyje aukštujų mokyklų programų atsirado tokios disciplinos, kaip tarybinè teisè, liaudies ūkio planavimas, TSRS istorija ir pan. Jau pirmaisiais sovietmečio metais komunistu partijos nurodymu pradèti steigti vadinamieji Liaudies universitetai (Bendžius, 1973, p. 121), kurie turejo formaliai gerinti išsimokslinimo lygi šalyje, ypač provincijoje. Tačiau svarbiausiais tokiu institucijų siekis neabejotinai buvo naujosios sovietinès ideologijos itvirtinimo propaganda, kurią buvo patogu vykdyti tokio tipo suaugusiuju švietimo istaigose. Pirmosios sovietinès okupacijos metais tokie Liaudies universitetai isteigti ne tik Vilniuje ir Kaune, bet ir Lazdijuose, Marijampolejje, Mažeikiuose, Taurageje, Vilkaviškyje, Kèdainiuose, jų veikloje privalejjo dalyvauti tikrujų universitetų ir kitų aukštujų mokyklų dèstytojai (Ten pat, p. 122).

Vykstant Antrojo pasaulinio karo veiksmams, keičiantis fronto linijai, 1941 metu vasarą Lietuvą užèmė vokiečiai. Tada Lietuvoje manyta, kad sovietų okupacija baigèsi ir visas socialinio, ūkinio, kultūrinio gyvenimo sritis bus galima grąžinti ị ikisovietini lygị. Laikinoji Lietuvos Vyriausybė Kauno universitetui sugrąžino senaji Vytauto Didžiojo pavadinimą, čia atkurtas Teologijos fakultetas ir ikurtas Filosofijos fakultetas (Vytauto Didžiojo universitetas: atmintis, žmonès, 
idejjos, 2008). Daugelyje aukštujų mokyklų suspèta panaikinti sovietų i̇vestas pseudomokslo disciplinas ir sugrą̌inti ankstesnius mokymo planus. Deja, teigiami pokyčiai buvo minimalūs. Nacių valdžia iš karto nurodè iš aukštujų mokyklų pašalinti visus dėstytojus ir studentus žydus. Profesoriai ir dauguma studentų žydų, nespeję pasislëpti, nacių sušaudyti ar nukankinti koncentracijos stovyklose. Vèliau nacių valdžia nurodè iš aukštujų mokyklų šalinti ir studentus lenkus bei rusus (Universitas Vilnensis 1579-2004, 2004, p. 42). Senajame Vilniaus universitete nacių valdymo laikotarpiu uždrausta ginti disertacijas, teikti mokslo laipsnius, išduoti aukštojo mokslo diplomus, apribotas mokslinis darbas. Aukštosiose mokyklose prasidejo antinacistinis lietuvių pasipriešinimas, kuriame aktyviai dalyvavo ir desstytojai, ir studentai.

1943 metų kovo ménesị nacių valdžia Lietuvoje uždarè visas aukštąsias mokyklas (Ten pat). Per visą okupacijos laikotarpi Vilniaus universitete vyko slaptos medicinos studijos. Grupé uždaryto Vytauto Didžiojo universiteto profesorių isteigė Suaugusiujų institutą (su aukštesniuoju technikos skyriumi ir medicinos kursais), kuris veike vienerius metus (Universiteto raida 1940-1950 m., 2012).

Aukštujų mokyklų laboratorijos, bibliotekos karo metu išvogtos, suniokotos, o patalpos dažniausiai virtusios kareivinėmis bei karo ligoninėmis. Keršydami už nepalankumą jų valdžiai, naciai kankino ir kalino koncentracijos stovyklose ne tik žydus, bet ir lietuvių intelektualus, profesorius.

\section{Antrosios sovietinès okupacijos pradžia, pokaris, XX a. 5-asis dešimtmetis}

1944 m. vasarą traukiantis vokiečiams ir sovietų armijai užèmus Vilnių, prasidejjo antroji sovietinė okupacija. Vytauto Didžiojo universitetas savo veiklą atnaujino 1944 m. rugpjūtị. 1946 m. Vytauto Didžiojo vardas ir vèl atimtas, universitetas vẻl pavadintas Kauno universitetu (Vytauto Didžiojo universitetas: atmintis, žmonès, idèjos, 2008). Aktyvūs universiteto studentai ịsitraukè ị Lietuvos pasipriešinimo sovietinei okupacijai organizacijas.

Senasis Vilniaus universitetas buvo verčiamas standartine sovietine aukštaja mokykla. Itvirtinus komunistų partijos diktata, atmestos 20 metų Lietuvoje puoselètos Europos universitetu tradicijos, grindžiamos valstybès nesikišimu į universitetų vidaus reikalus, savivalda, akademinėmis laisvėmis, tautiškumu, Lietuvos aukštosios mokyklos aklinai atskiriamos nuo Vakarų pasaulio. Ideologizuotam Vilniaus valstybiniam universitetui skirtas pagrindinis vaidmuo rengiant mokslo kadrus, kvalifikuotus sovietinius specialistus. 1941/1942 metais VU buvo 7 fakultetai: Istorijos ir filologijos, Teisès, Ekonomikos, Gamtos, Fizikos-matematikos, Chemijos ir Medicinos, mokèsi daugiau kaip 3000 studentu (Liekis, 2001, p. 103). 
Dèl mokslo ideologizavimo ypač nukentejjo humanitariniai ir socialiniai mokslai. I atleistujų dėstytojų, neitikusių sovietinei valdžiai, vietas buvo atsiunčiami darbuotojai iš Rusijos, net iš Kaukazo. Dauguma šių „specialistu““ - atsitiktiniai, menkos kvalifikacijos žmonès, nejautę pagarbos Lietuvai, jos žmonèms ir tradicijoms. Karo metais patyrusi nacių vykdytus žudymus ir sovietų trėmimus, akademinė Lietuvos bendruomenè labai sunyko, tačiau pokario metais sovietai bandè išnaikinti ir paskutiniuosius tautinio sąmoningumo ženklus.

Karui baigiantis ir pokariu akademinè visuomenè patyrè labai daug sunkumų. Trūko mokymo priemonių, kuro, nebuvo elektros, jauni dėstytojai stokojo patirties. Pokario metais švietimo ir mokslo plètrą stabdè ne tik ekonominè suirute, bet ir vis stiprejjantys sovietų valdžios persekiojimai, masinès tremtys i Sibirą, dèl kurių Lietuvos aukštasis mokslas neteko daugelio mokslininkų, intelektualų, bandžiusių išlaikyti naikinamo tautiškumo apraiškas.

Vis dèlto bandyta atkurti Lietuvos aukštąsias mokyklas, steigtos ir naujos. 1944-1946 metais atkurta Žemès ūkio akademija, laikinai besiglaudžianti Kaune. Akademijai plečiantis mieste esančių patalpų neužteko, 1946 metų pradžioje studentų gamybiniam mokymui perduota dalis Noreikiškių tarybinio ūkio, esančio netoli Kauno. Ten pradètas statyti Žemès ūkio akademijos miestelis (Liekis, 2000, p. 14). 1946 metais įkurti Žemès ūkio mechanizacijos, Hidromelioracijos ir žemètvarkos fakultetai, rengiantys Lietuvos žemès ūkiui reikalingus inžinierius.

1944 metais atkurtas mokytojus rengęs institutas, jis pavadintas Vilniaus valstybiniu pedagoginiu institutu (Visuotinè lietuvių enciklopedija, t. 10, p. 219). 1944 metais, vos pasitraukus frontui i Europos vakarus, institutas vẻl pradejjo mokslo metus. Tuo metu čia dirbo 16 dèstytojų ir studijavo 70 studentų (Vilniaus pedagoginis universitetas: 1935-1995 metai, 1995, p. 28-29).

1944 metais veiklą atnaujino Dailès institutas Kaune ir Dailès akademija Vilniuje. Remiantis tuometinès TSRS aukštojo mokslo ministerijos potvarkiu, 1951 metais abu institutai sujungti i vieną - Lietuvos TSR valstybinį dailès institutą (VDA istorija, 2012). Institute buvo Tapybos, Grafikos, Skulptūros, Architektūros kompozicijos ir projektavimo, Keramikos ir Dailiosios tekstilès katedros.

Po karo, 1945 metais rugsėjo mėnesi, kaip savarankiška aukštoji mokykla Kaune ịkurtas Lietuvos valstybinis kūno kultūros institutas (Stonkus, 2007, p. 61). Pirmiausia šioje aukštojoje mokykloje ikurtos Fizinio auklèjimo metodikos, Lengvosios atletikos ir žaidimų, Gimnastikos, Slidinėjimo, Plaukimo katedros. 1945-1946 metais institute jau dirbo 24 dèstytojai, tačiau jų reikèjo apie 50, tad reikalingi specialistai atsiųsti iš Leningrado ir Maskvos. Pirmoji šios aukštosios mokyklos laida išleista 1948 metais.

Kaune po karo atkurta Veterinarijos akademija. Nepaisant smarkaus 1946 metu pavasario potvynio, sunaikinusio didelę dalị vertingų laboratorijų ỉrenginių 
ir pastatų, $1946 \mathrm{~m}$. i̇steigtas naujas Zootechnikos fakultetas, kuris pradejjo rengti zootechnikos specialistus (Lazdauskienè, 1996, p. 46).

1948 metais Lietuvos TSR Ministrų Tarybos nutarimu Šiauliuose ikurtas mokytojų institutas (Gudavičius, Pabrèža, Šimaitis, 2008, p. 16). 1948-1989 mokslo metais veikè tik trys katedros (Kalbų ir literatūros, Fizikos-matematikos ir Gamtos-geografijos), jose tebuvo po keletą dèstytojų. I pirmą kursą priimti 128 studentai. Mokytojų institutas ikurtas kaip nepilna aukštoji mokykla, rengianti mokytojus progimnazijoms, vèliau - septynmetems mokykloms, nes pedagogų tuo metu Lietuvoje labai trūko. Čia buvo rengiami lietuviu kalbos ir literatūros, istorijos, matematikos ir fizikos, gamtos mokslo ir geografijos, o nuo 1949 metų - ir rusų kalbos mokytojai (Ten pat, p. 18).

1949 metais, sujungus Kauno valstybinę konservatoriją ir 1945 metais ikurtą Vilniaus valstybinę konservatoriją, isteigta LTSR valstybinė konservatorija (Narbutienè, 1993, p. 3). 1949 metais joje jau studijavo 230 studentų. Be prieškariu veikusių katedrų, ikurtos Lietuvių liaudies instrumentų, Muzikos teorijos ir istorijos katedros, nuo 1952 metu - Teatrinis fakultetas (Lietuvos TSR aukštosios mokyklos, 1965, p. 52-53).

1950 m. spalio 31 d. Sovietų Sajungos Ministrų Tarybos nutarimu Kauno universitetas (anksčiau vadinęsis Vytauto Didžiojo universitetu) pertvarkytas i dvi aukštojo mokslo institucijas - Kauno politechnikos institutą ir Kauno medicinos institutą (Universiteto raida 1940-1950 m., 2012).

Kauno politechnikos institutas vèliau laikytas didžiausia aukštaja mokykla Lietuvoje, turejusia 8 fakultetus Kaune, filialą su trimis fakultetais Vilniuje, vakarinius fakultetus Klaipėdoje, Panevėžyje ir Šiauliuose (Novodvorskis, 1964). 1965-1966 mokslo metais šiame institute iš viso mokèsi apie 17000 studentu (Lietuvos TSR aukštosios mokyklos, 1966, p. 15). Čia rengti chemijos technologijos, elektrotechnikos, lengvosios pramonès, mašinų gamybos, mechanikos, radioelektronikos, santechnikos, statybos ir kitų sričiu specialistai.

Kauno medicinos institutas septintajame-aštuntajame dešimtmečiais rengè ivairaus profilio gydytojus, stomatologus, provizorius ir medikus-biofizikus (Kauno medicinos institutas, 1967). Institute veikè du fakultetai: Gydomosios medicinos ir Stomatologijos-farmacijos. 1965/1966 mokslo metais institute mokèsi apie 2800 studentų (Lietuvos TSR aukštosios mokyklos, 1966, p. 47).

Buvusio Vytauto Didžiojo universiteto reorganizacija ị du institutus iš esmès susilpnino Lietuvos aukštaji mokslą, nes taip nutolta nuo Vakarų aukštojo mokslo sistemos, universalumo ir akademiškumo dvasios, buvo bandoma aukštąsias mokyklas profiliuoti, atsižvelgiant $\mathfrak{i}$ siaurus praktinius ūkinio gyvenimo poreikius. Sovietmečiu visapusiškai išsilavinių inteligentų nebereikejjo, aukštosiose moky- 
klose siekta rengti sovietinei santvarkai tinkamus „kadrus“, dirbančius „protini darbąa“" (Raškauskas, 2008, p. 98).

Klasikines aukštosios mokyklos gyvavimo ir mokslo plètros jose tradicijas sovietmečio pradžioje užgožè ir sovietinè socialinė politika, deklaravusi aukštojo mokslo masiškumo, prieinamumo visiems gyventojų sluoksniams ir kitus socialistinius principus: per visą sovietmetị aukštasis mokslas Lietuvoje buvo nemokamas, studentams buvo skiriamos valstybės stipendijos (Dẻl stipendijų skyrimo aukštujų ir specialiujų vidurinių mokyklų moksleiviams tvarkos. LTSR MT 1956 m. rugpjūčio 22 d. nutarimas Nr. 407, 1957, p. 485-486), studijų metais skiriami bendrabučiai, irengiamos valgyklos. Po studiju privaloma tvarka jauni specialistai būdavo įdarbinami - gaudavo paskyrimus dirbti konkrečiose ịmonèse, i̇staigose ar organizacijose (Dèl jaunujų specialistų, baigiančių aukštąsias ir specialiąsias vidurines mokyklas, paskirstymo (LTSR MT $1956 \mathrm{~m}$. vasario $11 \mathrm{~d}$. nutarimas Nr. 62, 1957, p. 340).

\section{Aukštojo mokslo plètra Lietuvoje XX a. 6-9 dešimtmečiais}

Po Stalino mirties $(1953 \mathrm{~m}$.) Lietuvos visuomenè ir akademinè bendruomenè vylèsi, kad beatodairiška mokslo ideologizacija bus pristabdyta, tačiau N. Chruščiovo valdymo politikos ,atlydys“ buvo trumpalaikis. Klasinè stojančiujų atranka ir ideologinè mokslo bei studiju priežiūra išliko visą likusį sovietmečio laikotarpi.

Aukštojo mokslo politizavimas vykdytas ir keičiant instituciju pavadinimus. Pavyzdžiui, 1955 metais Vilniaus universitetas pavadintas komunisto, politinio veikejjo Vinco Kapsuko vardu, o nuo 1971 metų universitetas imtas vadinti Vilniaus Darbo raudonosios vèliavos ordino valstybiniu Vinco Kapsuko universitetu (Universitas Vilnensis 1579-2004, 2004, p. 47). 1954 metais Šiauliu mokytoju institutas perorganizuotas i aukštają mokyklą - Pedagoginị institutą (Gudavičius, Pabrèža, Šimaitis, 2008, p. 20). O 1961 metais Lietuvos TSR Vyriausybès nutarimu institutui suteiktas partijos veikejjo Kazio Preikšo vardas (Lietuvos TSR aukštosios mokyklos, 1965, p. 43). 1974 m. Kauno politechnikos institutas pavadintas sovietinio politinio veikejo Antano Sniečkaus vardu (KPI 1950-1990 m., 2012). LTSR valstybinè konservatorija pavadinta Tautų draugystės ordino vardu (LTRS valstybinè konservatorija, 1983).

Aukštujų mokyklų sistemos formavimą sovietmečiu Lietuvoje iš esmès užbaigẻ dar vienos aukštosios mokyklos įūrimas Vilniuje. 1969 metais reorganizavus Kauno politechnikos instituto Vilniaus filialą ikurtas Vilniaus inžinerinis statybos institutas (Nakas, 2006). Taip Vilniuje atsirado savarankiška aukštoji technikos mokykla. Tuo metu veikè 26 katedros, jose dirbo 290 dèstytoju, studijavo apie 
3500 studentu. Vilniaus inžineriniame statybos institute sovietmečiu veikè Mechaninès technologijos, Prietaisų gamybos, kiek vẻliau - Miestų statybos, Architektūros, Statybos, Komunalinio ūkio fakultetai.

Taigi aštuntojo dešimtmečio pradžioje Lietuvoje susiklostė aukštojo mokslo institucijų sistema, kurią sudarè vienas universitetas Vilniuje ir 10 institutų bei akademijų Vilniuje, Kaune ir Šiauliuose. Pažymètina, kad per visą sovietmeti aukštujų mokyklų struktūra keitėsi, nes valdžios nurodymu buvo būtina dalị fakultetų ar jų filialų perkelti i kitus, dažnai mažesnius miestus. Taip, pavyzdžiui, 1971 metais Klaipėdoje įsteigtas Šiaulių pedagoginio instituto muzikos fakultetas, vèliau tapęs Lietuvos konservatorijos Klaipedos fakultetu, o 1975 metais iš Šiauliu ¡ Klaipedą perkelta ikimokyklinio auklejimo specialybe ir ikurtas atskiras Ikimokyklinio auklëjimo fakultetas (Gudavičius, Pabrěža, Šimaitis, 2008, p. 20). Kitos aukštosios mokyklos turèjo savo filialus Panevėžyje, Šiauliuose, Kaune, Kapsuke (dab. Marijampoleje) ir kt.

Formaliai aukštaja mokykla buvo vadinama ir Vilniaus aukštoji partinė mokykla, ikurta 1956 metais, pertvarkius dar 1945 metais įsteigtą dvimetę respublikinę partinę mokyklą (Skardis, 1987, p. 356). Tai buvo aiškiai apibrèžtos specifinès paskirties institucija, pavaldi LTSR Komunistų partijos Centro komitetui, rengianti partinius funkcionierius. Yra duomenų, kad 1958/1959 mokslo metais joje mokèsi 314 žmoniu (Lietuvos TSR aukštosios mokyklos, 1965, p. 28) - daugiausia vadovaujantị darbą îvairiose i̇monėse ir įstaigose dirbantys asmenys, kurie, siekdami profesinès karjeros, sovietmečiu būtinai turejjo būti partijos nariai ir vadinamosiose partinèse mokyklose išklausyti atitinkamas marksistinès ideologijos disciplinas. 1962 metais Vilniaus aukštoji partinė mokykla tapo tarprespublikine, i ją studijuoti vyko funkcionieriai iš Latvijos ir Estijos (Lietuva brolišku tautu šeimoje, 1980, p. 102-104). Po nepriklausomybès atkūrimo, 1990 metais, ji panaikinta, pastatai perduoti Vilniaus pedagoginiam institutui. Dabartiniu metu buvusios aukštosios partinès mokyklos diplomai Lietuvoje kaip aukštojo mokslo baigimo dokumentai nepripažistami.

\section{Lietuvos aukštasis mokslas Atgimimo metais}

Sovietiniu laikotarpiu tikroji lietuviškoji akademinė tradicija gyvavo „pogrindyje“, dažniau - užsienyje, kur ji ne tik išliko, bet išeivijoje vystėsi ilgus dešimtmečius iki valstybingumo atkūrimo. Akademinès veiklos kryptys išryškejjo periodiniuose ir tęstiniuose leidiniuose, kurie leisti Vakarų Europoje ir JAV: Lietuvių katalikų mokslo akademijos ir Lituanistikos instituto suvažiavimų darbai, tarpdisciplininis žurnalas anglų kalba „Lituanus“, intelektiniai žurnalai „Aidai“, „Metmenys“, „Mūsų Vytis“. Padvelkus permainų vejjams Sovietų Sajungoje ir iš 
naujo bundant Lietuvos laisvès viltims, ypatingą reikšmę igijo Mokslo ir kūrybos simpoziumai, inicijuoti vieno iš Akademinio skautų sajūdžio lyderių, Kalifornijos universiteto profesoriaus Algirdo Avižienio. Būtent šie simpoziumai, siekę sutelkti viso pasaulio lietuviu akademikus ir intelektualus, brandino VDU atkūrimo, jo būsimo pavidalo ir misijos idèjas. VI simpoziume, kuris vyko Čikagoje 1989 m. lapkričio 22-26 d., išrinkti 48 VDU Atkuriamojo Senato nariai (Vytauto Didžiojo universitetas: atmintis, žmonès, idèjos, 2008, p. 68). Vytauto Didžiojo universiteto atkūrimas - vienas didžiausių akademinių laimèjimų Lietuvoje sovietmečio pabaigoje. Tuo metu jis tapo ir pirmaja autonomiška aukštaja mokykla.

Sovietmečiu Lietuvos aukštojo mokslo institucijos garsejjo Sovietu Sajungoje savo mokslininkais, veikla, specialistų rengimo kokybe, akademine drąsa. 1989 metais Lietuvoje buvo 13 aukštujų mokyklų, 67 mokslinio tyrimo institutai ir ju padaliniai, 15367 mokslo darbuotojai (Liekis, 2003, p. 143, 152). Nepaisant labai sudètingų politinių ir socialinių-ekonominių sąlygų (Čepaitienè, 2003, p. 74-80; Klumbys, 2008, p. 139-161), būtent Lietuvos akademinè inteligentija, profesūra ir studentai buvo pirmosiose Atgimimo Sajūdžio gretose ir įdejjo nemažai pastangu 1990 metais atkuriant valstybės nepriklausomybę.

\section{Išvados}

1. Iki 1940 metų Lietuvoje jau buvo susiformavęs aukštojo mokslo institucijų „,branduolys“, apėmęs esmines valstybei ir visuomenei aktualias sritis. Aukštojo mokslo plètros eigą kardinaliai pakeitė sovietinė okupacija ir II pasaulinis karas.

2. Aukštojo mokslo koncepcijos, ideologijos, struktūros ir turinio pokyčiai, vykę 1940-1945 metais valdant sovietams-naciams-sovietams, menkino ir naikino iki 1940 metu pasiektą akademinị įdirbị, visokeriopai silpnino tiek intelektini, tiek ir materialuji Lietuvos mokslo potencialą.

3. Antrojo pasaulinio karo pabaigoje ilgiems dešimtmečiams Lietuvoje įsivyravus sovietinei santvarkai, aukštasis mokslas pertvarkytas ji toliau tikslingai ideologizuojant, atsižvelgiant i Sovietų Sajungos komunistų partijos tikslus. XX a. 7 dešimtmečio pabaigoje Lietuvoje ilgainiui susiformavo aukštojo mokslo institucijų sistema, telkianti vieną universitetą ir 10 aukštojo mokslo studijas vykdančių institutų bei akademijų, rengiančių gana siauro profilio specialistus - ,kadrus“ ivairioms sovietinès visuomenès institucijoms.

4. XX a. 9-ajame dešimtmetyje kilęs Atgimimo judejimas ir išeivijos mokslininkų pastangos sudare prielaidas dar sovietinėje Lietuvoje atkurti Vy- 


\title{
tauto Didžiojo universitetą, taip pradedant kokybiškai naują aukštojo mokslo raidos etapa, kuris prasidejo po 1990-ujų - jau nepriklausomoje valstybèje.
}

\author{
Gauta 20131010 \\ Pasirašyta spaudai 20140214
}

\section{Literatūra}

Aukštosios mokyklos kūrimasis ir vystymasis Kaune. (1967). Vilnius: Mintis.

Bendžius, A. (1973). Bendrojo lavinimo ir aukštoji mokykla tarybu Lietuvoje 1940-1970 m. Kaunas: Šviesa.

Bružauskas, V., Čaplikas, J. Kirstukas, J. ir kt. (2007). Agrosocialiniu mokslu ir studiju raida Lietuvoje. Kaunas: Akademija.

Čepaitienė, R. (2003). Sovietmetis Lietuvos kultūros istorijos šviesoje: projekto bandymas. Menotyra, nr. 2 (31): 74-80

Dẻl jaunujų specialistų, baigiančių aukštąsias ir specialiąsias vidurines mokyklas, paskirstymo (LTSR MT 1956 m. vasario 11 d. nutarimas Nr. 62). (1957). Lietuvos TSR įstatymu, AT Prezidiumo isaku ir Vyriausybés nutarimu chronologinis rinkinys, t. 5 .

Dèl stipendijų skyrimo aukštujų ir specialiujų vidurinių mokyklų moksleiviams tvarkos (LTSR MT $1956 \mathrm{~m}$. rugpjūčio 22 d. nutarimas Nr. 407). (1957). Lietuvos TSR įstatymu, AT Prezidiumo įsaku ir Vyriausybès nutarimu chronologinis rinkinys, t. 5 .

Genzelis, B. (2001). Lietuvos kultūros istorijos metmenys. Kaunas: VDU.

Germanas, V. (1987). Klaipėdos prekybos instituto vaidmuo rengiant ekonomistus. Lietuvos TSR aukštuju mokyklu mokslo darbai. Ekonomika, t. 31.

Gudavičius, A., Pabrèža, J., Šimaitis S. (2008). Šiauliu universitetas: ištakos ir dabartis. Šiauliai: ŠU 1-kla.

Jaunuoli, pasirink specialybę aukštojoje mokykloje. (1964). Vilnius: Valstybinis aukštojo ir specialiojo vidurinio mokslo komitetas.

Kauno medicinos institutas. (1967). Kaunas.

Klaipėdos pedagoginis institutas. (2006). Visuotiné lietuviu enciklopedija, t. 10. Vilnius: Mokslo ir enciklopediju leidybos institutas.

Klumbys, V. (2008). Lietuvos kultūrinis elitas sovietmečiu. Lietuvos etnologija, nr. 8(17).

KPI 1950-1990 m. Prieiga internete: http://muziejus.ktu.lt/istorija/kpi-1950-1990-m

Lazauskienè, A. (2009). Pirmoji aukštoji mokykla Šiauliuose: Prekybos institutas (1939-1944). Šiauliai: S̆U 1-kla.

Lazdauskienė, V. (1996). Lietuvos veterinarijos akademijos įkūrimas. Lietuvos veterinarijos akademija: praeitis, dabartis, ateitis. Vilnius: Informacijos ir leidybos centras.

Leonavičius, A. (1961). Akademinès grupės vadovas. Apie Kauno aukštujų mokyklų akademinių grupių vadovų pasitarimą studentų auklèjimo klausimais. Kauno tiesa, kovo 24 d.

Liekis, A. (2001). Lietuvos mokslų akademija 1941-1990 m. Lietuvos mokslas, kn. 31.

Liekis, A. (2003). Lietuvos akademinių institucijų mokslo darbuotojai 1944-1990 metais: statistinè analizè. Informacijos mokslai, t. 27.

Liekis, A. (2003). Mokslo ir studijų sistemos formavimas Lietuvoje SSRS okupacijos metais. Akademinè edukologija, t. 1.

Liekis, A. (red.) (2000). Lietuvos žemès ūkio universitetas 1924-1999. Lietuvos mokslas, kn. 25.

Lietuva brolišku tautu šeimoje (Lietuvos TSR bendradarbiavimas su broliškomis tarybinèmis respublikomis brandaus socializmo salygomis 1961-1975). (1980). Vilnius.

Lietuvos TSR aukštosios mokyklos. (1965). Vilnius: Lietuvos TSR Ministrų Tarybos Valstybinis aukštojo ir specialiojo vidurinio mokslo komitetas.

Lietuvos TSR Ministrų tarybos 1964 metų birželio 23 d. nutarimas Nr. 290 „Dèl aukštojo ir specialiojo vidurinio neakivaizdinio bei vakarinio mokslo tolesnio gerinimo“. (1964). Lietuvos TSR AT ir Vyriausybès žinios, nr. 19. 
LTRS valstybine konservatorija. (1983). Vilnius: LTSR aukštojo ir specialiojo mokslo ministerija.

Mironas, R. (1958). Apie antireliginį auklejjimą aukštosiose mokyklose. Tarybinis mokytojas, gruodžio 25 d.

Nakas, A. (2006). Vilniaus Gedimino technikos universiteto raida, 1956-2006. Vilnius: Technika.

Narbutienè, O. (1993). Lietuvos muzikos akademijos ištakos. Muzikos akademijos 60-metis: dabartis ir ateities perspektyvos. Vilnius.

Novodvorskis, A. (1964). Kauno politechnikos institutas. Kaunas: KPI 1-kla.

Raškauskas, K. (2008). Sovietinès Lietuvos inteligentija: Sąvokos konstravimas. Darbai ir dienos, nr. 49.

Skardis, A. (1987). Respublikinė partinė mokykla. Tarybu Lietuvos enciklopedija, t. 3. Vilnius: Vyriausioji enciklopedijų redakcija.

Sprindys, K. (1951). Daugiau dėmesio neakivaizdininkams. Tarybiné mokykla, nr. 11.

Stonkus, S. (2007). Lietuvos aukštasis kūno kultūros mokslas: žmonès ir darbai. Kaunas: Lietuvos kūno kultūros akademija.

Tijūnèlienè, O. (1996). Mokytoju rengimas Respublikos pedagoginiame institute (Klaipéda: 1935-1939 m.). Klaipèda: KU 1-kla.

Universitas Vilnensis 1579-2004. (2004). Prieiga internete: http://www.vu.lt/site_files/InfS/Leidiniai/Vilniaus universitetas_1579_2004.pdf

Universiteto raida 1940-1950 m. Prieiga internete: http://muziejus.ktu.lt/istorija/universiteto-raida-1940-1950-m

VDA istorija. Prieiga internete: http://www.vda.lt/index.php/pageid/897

Vilniaus pedagoginis universitetas: 1935-1995 metai. (1995). Vilnius.

Visockas, A. (1986). Šiaulių prekybos institutas ir jo veikla 1939-1944. Lietuvos istorijos metraštis. Vilnius.

Vytauto Didžiojo universitetas: atmintis, žmonès, idejos. (2008). Kaunas: VDU.

Volenskytè, R. (1952). Ideologinis darbas aukštosiose mokyklose. Komjaunimo tiesa, vasario 29 d.

\section{THE SYSTEM OF HIGHER EDUCATION INSTITUTIONS IN LITHUANIA IN 1940-1990: FEATURES OF DEVELOPMENT}

\section{Aušrinė Zulumskytė}

\section{Summary}

The aim of his article - to reveal development features of the Higher Education System in Lithuania in 1940-1990 (in the Soviet era).

The oldest higher education institute in Lithuania is Vilnius University, which was founded in 1579. Other independent Lithuanian institutes of higher education, or higher education status-oriented schools, were founded during the interwar period (1918-1939). In 1940 Lithuania offered the following: Vytautas Magnus University, Agricultural Academy, Kaunas Conservatory, Institute of Commerce, Higher Physical Education courses, Republic Pedagogical Institute, Veterinary Medicine Academy and Applied Decorative Arts School (later the Vilnius Academy of Arts).

In the summer of 1940, the Soviet Union occupied Lithuania and higher education institutes were transformed according to the Soviet system and ideology, as in the other Baltic countries. Vytautas Magnus University lost its historic name and 
became Kaunas University. The Faculty of Theology and Philosophy was immediately closed by Soviets. Activities of student fraternities and sororities and student unions were stopped. However, the students of Vilnius University did not give up, and were active in the underground resistance. They were among the organizers and participants of uprisings against the occupiers in 1941.

The Soviet regime brutally changed the study process. These changes were similar to other Baltic countries: students and professors who opposed the Soviet regime were fired. Many intellectuals and well-educated people were exiled to Siberia; many of them never returned. To escape the Soviets, a large number fled to the West after World War II. The curriculum in higher education institutes was rapidly and radically changed. Military training, Marxism-Leninism and Paramilitary medical practice were introduced in all education institutions. Courses such as Soviet law, planning of the national economy and USSR history were introduced in the curriculum of many higher education institutes.

During the first year of Soviet rule, the Communist Party required the creation of 'People's universities'. Their official purpose was to improve the level of education in the country, especially in the provinces. However, the most important goal of these institutions was, undoubtedly, propaganda of Soviet ideology.

Nazi Germany occupied Lithuania in the summer of 1941. The people of Lithuania hoped that social, economic and cultural life would return to pre-Soviet time, as did Latvians and Estonians. At the beginning it looked hopeful: Kaunas University once again became Vytautas Magnus University; the Soviet pseudo-science disciplines were cut and the previous curriculum was brought back. However, the positive changes ended quickly. The laboratories and libraries of higher education institutes were unused or damaged, and the premises were usually turned into barracks or military hospitals. In retribution for resistance to their authority, the Nazis tortured and imprisoned many in concentration camps. Not only Jews, but also Lithuanian intellectuals and professors suffered Nazi oppression. In March 1943, the Nazi government closed all higher education institutes in Lithuania.

In the summer of 1944, the second Soviet occupation of Lithuania began. Vytautas Magnus University resumed activities in August 1944, but in 1946 the name of the institution was again changed to Kaunas University. Vilnius University was forced to comply with Soviet higher education institution standards and the university was renamed 'Order of the Red Flag of Labour Decorated Vinco Kapsuko Vilnius State University'. Vilnius State University (VSU) was key in the training of researchers and skilled Soviet specialists.

In spite of political and economical difficulties and the Soviet occupation, Lithuanian higher education tried to recover after World War II. New institutes were established. The Academy of Agriculture was reopened in 1944-1946 and a speci- 
al complex of buildings known as the 'Agricultural Academy Town' near Kaunas had begun to be built. In 1946, Faculties of Agricultural Mechanization, Reclamation and Land were founded where highly qualified engineers for Lithuanian agriculture were prepared. The central government decided to step up the training of specialists for agricultural sectors, so the men who studied in the Academy were not required to serve in military service. Therefore, this institute became especially popular among young men.

In 1944, Kaunas Art Institute and the Academy of Arts in Vilnius resumed their activities. The USSR Ministry of Higher Education passed a resolution in 1951 that merged both institutions into one - the State Institute of Art with departments of painting, graphics, sculpture, architectural composition and design, ceramics and fine textile. In September 1945, the Lithuanian State Institute for Physical Education was established in Kaunas as an autonomous higher education institute with methodology departments for physical training, athletics and games, gymnastics, skiing, and swimming. The Veterinary Medicine Academy was also reopened in Kaunas. In 1949 Kaunas State Conservatory and Vilnius State Conservatory, founded in 1945, were united creating the National Conservatory. The departments of Lithuanian folk instruments, music theory and history were founded, and in 1952 the drama department was added.

On 31 October 1950, the Council of Ministers of the USSR passed a resolution reorganizing, Kaunas University dividing it into two institutions of higher education: Kaunas Polytechnic Institute and Kaunas Medical Institute. The reorganization of the previous Vytautas Magnus University into two institutions actually weakened Lithuanian higher education - it stepped away from the classic meaning of university education in which the study of medicine is integral part.

Kaunas Polytechnic Institute became the largest institution of higher education in Lithuania. Eight faculties operated in Kaunas and a branch with three faculties opened in Vilnius, as well as evening classes in Klaipèda, Panevėžys and Šiauliai. In 1965/1966 about 17,000 students attended the Institute. Specialists in chemical technology, electrical engineering, light industry, mechanical engineering, radio electronics, plumbing, construction and other fields were prepared there.

Kaunas Medical Institute had two faculties: General Medicine and DentalPharmaceutical. In 1965-1966 about 2800 students attended the Institute. In the 1970s and 1980s, multidisciplinary doctors, dentists, pharmacists and doctor-biophysicists were educated there.

A special institution of higher education was the Vilnius Higher Party Institute, founded in 1956 after the reorganization of the Republican Party School, founded in 1945. It was an institution with a special purpose and subordinate to the Central Committee of the Communist Party of USSR. Party leaders were prepared there. 
In 1958-1959 a total of 314 people were trained there. Most of them were in top positions in various institutions of Soviet society and therefore were obligated to become members of the Communist Party. Their professional competence was 'strengthened' with ideology and they studied subjects relevant to Soviet ideology. After regaining independence in 1990, the Vilnius Higher Party Institute was closed. Currently, diplomas issued by this school are not recognized in Lithuania as documents of academic qualification.

The true Lithuanian academic tradition existed in the underground and more often abroad. The direction of academic activities was reflected in scientific periodical publications in Western Europe and the USA. During the period of Sajūdis, Science and Arts symposia gained special significance. These events were initiated by professor A. Avižienis from the University of California. The Science and Arts symposia in Chicago in 1989 mobilized Lithuanian academics and intellectuals from all over the world to work on restoration of Vytautas Magnus University. This is one of the largest academic achievements in Lithuania at the end of the Soviet era.

Lithuanian higher education institutions in the Soviet Union were famous for their academics, activities, specialist training quality, and academic progress. In 1989 in Lithuania, there were 13 institutes of higher education Despite the extremely difficult political and socioeconomic conditions, Lithuanian academics, intellectuals, professors and students were on the front lines of the Sajūdis movement and they made invaluable efforts in the restoration of independence during the 1990s. 